\title{
Assisting Natural Wind Pollination of Field Tomatoes with an Air Blower Enhances Yield
}

\author{
H.Y. Hanna ${ }^{1}$ \\ Louisiana State University Agricultural Center, Louisiana Agricultural \\ Experiment Station, Red River Research Station, P.O. Box 8550, Bossier City, \\ LA 71113-8550
}

Additional index words. supplemental pollination, insect pollination, vibration of tomato plants, Lycopersicon esculentum

\begin{abstract}
Studies were conducted in 1994,1995, and 1997 to determine the effect of assisting natural wind pollination using an air blower on yield and fruit characteristics of three tomato (Lycopersicon esculentum Mill.) cultivars. Tomato plants and flowers in the air blower-assisted treatment were vigorously vibrated at midday every other day on sunny days for 4 weeks. Plants and flowers in the control treatment were exposed to ambient wind only. Early yield was significantly greater in the treated plants in 2 years, marketable and total yields for all tested cultivars were significantly greater in all years, and yields of culls were significantly lower in 2 years. Fruit weight and diameter and number of seeds per fruit were increased in all years.
\end{abstract}

The tomato is $>99 \%$ naturally self-pollinated (Groenewegen et al., 1994). The flower of most commercial cultivars has a short style that places the stigma well within the anther tube, assuring self-pollination and virtually eliminating the opportunity for outcrossing (Rick, 1978). Pollen is shed within the individual flowers during anthesis when there is a strong enough vibrating force, such as wind, to shake the plant and flower (Snyder, 1997). Insect pollination of field tomatoes is very rare and has no significant effect on fruit set and yield (Quiros and Marcias, 1978). Most of the investigations on pollinating tomato flowers by electric vibrators have been conducted in greenhouses in Europe (Kerr and Kribs, 1955). Results have indicated that this treatment was necessary to obtain good fruit set and size in the absence of wind (Verkerk, 1957).

Occasionally, yields of field-grown tomatoes are poor under unfavorable conditions, such as low temperature during early spring (Papadopoulos, 1991) or high temperature during summer (Abdul-Baki and Stommel, 1995; Peet and Bartholemew, 1996). Shelby et al. (1978) indicated that insufficient pollination under unfavorable conditions was a major cause of decreased tomato production.

Received for publication 8 Oct. 1998. Accepted for publication 9 Feb. 1999. Approved for publication by the director of the Louisiana Agricultural Experiment Station as manuscript no. 98-84-0509. Mention of a trademark, proprietary product, or vendor does not constitute a guarantee or warranty of the product by the Louisiana State Univ. Agricultural Center and does not imply its approval to the exclusion of other product or vendor that also may be suitable. The cost of publishing this paper was defrayed in part by the payment of page charges. Under postal regulations, this paper therefore must be hereby marked advertisement solely to indicate this fact.

${ }^{1}$ Professor
One would assume that field tomatoes are subject to enough natural wind to vibrate the plants and release enough pollen for maximum self-pollination and optimum yield. However, the wind in open fields may not always be strong enough to vibrate the plants and release the amount of pollen needed for maximum fruit weight and size, or may be insufficient during weather conditions that are optimum for maximum pollen release. This study was conducted to determine if using an air blower to assist natural wind-pollination would enhance the yield of three tomato cultivars.

\section{Materials and Methods}

Studies were conducted from April to July in 1994, 1995, and 1997 on a Norwood sandy loam soil (Typic Udifluvent; fine-silty, mixed, calcareous, thermic) at the Red River Research Station, Bossier City, La. The cultivars Celebrity and Sunny were planted during the first week of Apr. 1994 and 1995, and the cultivars Celebrity and Heatwave during the second week of Apr. 1997. The experimental design was a $2 \times 2$ factorial, arranged in a randomized complete block with four replications. Treatments were: 1) air blower-assisted vs. control plants; and 2) 'Celebrity' vs. 'Sunny' in 1994 and 1995 and 'Celebrity' vs 'Heatwave' in 1997. Tomato seeds were sown in no. 38 growing trays (Growing Systems, Inc., Milwaukee). Transplants were raised in a soilless mix (Pro-Mix BX, Premier Brands, Yonkers, N.Y.) for 5 weeks in the greenhouse before being planted in the field in $1.5 \times 30-\mathrm{m}$ plots. Black polyethylene mulch (1.5 m wide), and drip irrigation tubing were applied to the test plots with a mulch layer (Kennco Mfg., Inc., Ruskin, Fla.). Transplants were set to a $7.5-\mathrm{cm}$ depth and spaced at $45 \mathrm{~cm}$ within the row using a mechanical planter. Tomato plants in the air blower-assisted treatment were vig- orously vibrated every other day around noon on sunny days using an Echo P.B.-1000 air blower (Echo Inc., Lake Zurich, Ill.). The vibration started at the beginning of anthesis and continued for 4 weeks. The air outlet was held $\approx 30 \mathrm{~cm}$ from the tomato plant, and the blower was operated at high speed, directing the air toward the flower clusters for $2 \mathrm{~s}$. Plants in the control treatment were left to be pollinated by natural wind only. Other cultural practices consisted of standard recommendations for growing tomatoes for commercial production (Boudreaux, 1998). Tomatoes were harvested from the entire plot at the pink stage three times per week for 3 to 4 weeks. Fruit with blossom-end rot and other defects were removed, and the rest were graded by a machine (Tew Manufacturing Corp., Penfield, N.Y.) according to U.S. Dept. of Agriculture standards (U.S. Dept. of Agriculture, 1991). Early fruiting was determined by weighing fruit graded medium or larger in the first three harvests, and marketable yield was the sum of the same grades in all harvests. Cull yield was the weight of all fruit with visible defects and small size, and total yield was the sum of all harvested fruit. Mean fruit weight and diameter were determined on a 50-fruit sample collected at random around mid-harvest. During the 1997 season, seeds were extracted from a 10-fruit sample and the mean seed number per fruit was determined. Data were analyzed by analysis of variance (SAS Institute, 1990).

\section{Results and Discussion}

Air blower-assisted plants of each cultivar produced significantly greater early yield than did control plants in 1995 and 1997. Within cultivars, marketable and total yields were significantly greater during each year, and yields of culls were significantly lower in 1994 and 1995. Fruit weight and diameter and the number of seeds per fruit were increased in all years (Table 1). Yield of 'Sunny' was significantly greater than that of 'Celebrity' in 1995. Interactions between treatment and cultivar for all evaluated traits were nonsignificant except for fruit weight in 1994 (Table 1). Thus, the beneficial effect of the treatment was not limited to a specific cultivar. We did not determine pollen number on the stigma of treated and nontreated flowers, but the yield data suggest that vibration of tomato plants by natural wind in open fields was not sufficient to release enough pollen for producing fruit of maximum size. The data also suggest that vibrating tomato plants with an air blower around midday on sunny days, i.e., under optimum conditions for pollination, may have forced the anthers to release more pollen, resulting in more efficient pollination and fertilization. As a result, seed number and fruit weight and diameter were increased, yield of culls was reduced, and early, marketable, and total yields were enhanced. Verkerk (1957) indicated that the more pollen used in pollination, the more seed set, resulting in fastergrowing fruit and a more profitable crop. Shelby et al. (1978) reported that yield of 
Table 1. Effects of use of an air blower to assist in pollination on yield, weight, and diameter of tomato fruit.

\begin{tabular}{|c|c|c|c|c|c|c|c|c|}
\hline \multirow[b]{3}{*}{ Cultivar } & \multirow[b]{3}{*}{ Air blower } & \multirow{2}{*}{\multicolumn{4}{|c|}{ Yield $\left(\mathrm{t} \cdot \mathrm{ha}^{-1}\right)$}} & \multicolumn{3}{|c|}{ Fruit } \\
\hline & & & & & & \multirow{2}{*}{$\begin{array}{l}\mathrm{Wt} \\
(\mathrm{gm})\end{array}$} & \multirow{2}{*}{$\begin{array}{c}\text { Diam } \\
(\mathrm{cm})\end{array}$} & \multirow{2}{*}{$\begin{array}{l}\text { Seed } \\
\text { (no.) }\end{array}$} \\
\hline & & Early & Marketable & Total & Culls & & & \\
\hline & \multicolumn{8}{|c|}{1994} \\
\hline \multirow[t]{2}{*}{ Celebrity } & Yes & 5.6 & 32.5 & 37.6 & 5.1 & 231 & 6.3 & \\
\hline & No & 3.5 & 23.0 & 30.2 & 7.2 & 187 & 5.9 & \\
\hline \multirow[t]{2}{*}{ Sunny } & Yes & 5.5 & 32.5 & 37.0 & 4.6 & 249 & 6.3 & \\
\hline & No & 4.5 & 24.9 & 31.6 & 6.7 & 223 & 6.0 & \\
\hline \multicolumn{9}{|l|}{ Significance } \\
\hline Treatment $(\mathrm{T})$ & & NS & $* *$ & $*$ & $* * *$ & $* * *$ & $* *$ & \\
\hline Cultivar (C) & & NS & NS & NS & NS & $* * *$ & NS & \\
\hline \multirow[t]{2}{*}{$\mathrm{T} \times \mathrm{C}$} & & NS & NS & NS & NS & $*$ & NS & \\
\hline & \multicolumn{8}{|c|}{1995} \\
\hline \multirow[t]{2}{*}{ Celebrity } & Yes & 7.1 & 41.4 & 43.9 & 2.5 & 219 & 6.4 & \\
\hline & No & 5.2 & 33.4 & 38.4 & 5.0 & 195 & 5.9 & \\
\hline \multirow[t]{2}{*}{ Sunny } & Yes & 10.1 & 50.5 & 52.0 & 1.6 & 250 & 6.7 & \\
\hline & No & 7.6 & 43.0 & 46.1 & 3.1 & 221 & 6.4 & \\
\hline \multicolumn{9}{|l|}{ Significance } \\
\hline Treatment & & $*$ & $* *$ & $*$ & $* *$ & $*$ & $*$ & \\
\hline Cultivar & & $*$ & $* *$ & $* *$ & $* *$ & $*$ & $*$ & \\
\hline \multirow[t]{2}{*}{$\mathrm{T} \times \mathrm{C}$} & & NS & NS & NS & NS & NS & NS & \\
\hline & \multicolumn{8}{|c|}{1997} \\
\hline \multirow[t]{2}{*}{ Celebrity } & Yes & 11.2 & 44.3 & 48.5 & 4.2 & 218 & 7.8 & 186 \\
\hline & No & 8.9 & 34.3 & 38.7 & 4.4 & 204 & 7.5 & 138 \\
\hline \multirow[t]{2}{*}{ Heatwave } & Yes & 13.4 & 39.2 & 44.8 & 5.6 & 219 & 7.8 & 97 \\
\hline & No & 7.3 & 28.1 & 33.5 & 5.4 & 206 & 7.6 & 86 \\
\hline \multicolumn{9}{|l|}{ Significance } \\
\hline Treatment & & $* *$ & $* *$ & $* *$ & NS & $*$ & $*$ & $* *$ \\
\hline Cultivar & & NS & NS & NS & $*$ & NS & NS & $* * *$ \\
\hline $\mathrm{T} \times \mathrm{C}$ & & NS & NS & NS & NS & NS & NS & NS \\
\hline
\end{tabular}

tomatoes grown under unfavorable conditions of high temperature was markedly improved by supplemental hand pollination. He concluded that insufficient pollination probably was the major cause of yield reduction.

Thousands of acres of fresh-market tomatoes are produced each year in the southern United States using the stake and tie system (Konsler and Gardner, 1990). In this system, tomato plants are kept in a straight upward position by tying them with several strands of string to wooden stakes $1.5 \mathrm{~m}$ high. This system may restrict plant movement by natural wind, leading to insufficient release of pollen at the right time, and resulting in less sprayers could use the same equipment to vibrate their tomato plants on sunny days for better pollination and yield, or another device could be developed to vibrate field tomatoes during peak blooming.

\section{Literature Cited}

Abdul-Baki, A.A. and J.R. Stommel. 1995. Pollen viability and fruit set of tomato genotypes under optimum and high-temperature regimes. HortScience 30:115-117.

Boudreaux, J.E. 1998. Commercial vegetable production recommendations. Louisiana Coop. Ext. Serv. Publ. 2433.

Groenewegen, C., G. King, and B.F. George. 1994. Natural cross pollination in California commercial tomato fields. HortScience 29:1088.

Kerr, E.A. and L. Kribs. 1955. Electrical vibrators as an aid in greenhouse tomato production. Agr. Inst. Rev. 10:34.

Konsler, T.R. and R.G. Gardner. 1990. Commercial production of staked tomatoes in North Carolina. North Carolina Agr. Ext. Publ. AG-405.

Papadopoulos, A.P. 1991. Growing greenhouse tomatoes in soil and in soilless media. Agriculture Canada Publ. 1865/E.

Peet, M.M. and M. Bartholemew. 1996. Effect of night temperature on pollen characteristics, growth, and fruit set in tomato. J. Amer. Soc. Hort. Sci. 121:514-519.

Quiros, C.F. and A. Marcias. 1978. Natural cross pollination and pollinator bees of the tomato in Celaya, Central Mexico. HortScience 13:290-291.

Rick, C.M. 1978. The tomato. Sci. Amer. 239(2):7689.

Robinson, R.W., S. Shannnon, and W. Mishanec. 1965. Low temperature influences pollen production and fruit set of tomatoes. Farm Res. 31(1):13-15.

than optimum yields. Another factor that could reduce early and total yields is the very early planting practiced by southern growers to obtain better prices for early crops. Occasionally, these plants are exposed to low night temperatures, which could reduce pollen production (Robinson et al., 1965). More vibrating force may be required to release this limited amount of pollen.

Using an air blower to assist in pollinating thousands of acres of trellised tomato in the south is not feasible. However, many home gardeners own similar devices and will be more than willing to use them to maximize the yield of their plants. Growers who use air-blast
SAS Institute. 1990. SAS/STAT user's guide, ver. 6, 4th ed. SAS Inst., Cary, N.C.

Shelby, R.A., W.H. Greenleaf, and C.M. Peterson. 1978. Comparative fertility in heat tolerant and heat sensitive tomatoes. J. Amer. Soc. Hort. Sci. 103:778-780.

Snyder, R.G. 1997. Greenhouse tomato handbook. Mississippi State Univ. Ext. Serv. Publ. 1828.

U.S. Dept. of Agriculture. 1991. United States standards for grades for fresh tomatoes. Agr. Mkt.

Verkerk, K. 1957. The pollination of tomatoes. Neth. J. Agr. Sci. 5:37-54. Serv. 7 CFR 51. 